\title{
Legal Environment for Foreign Investments in Poland
}

\begin{abstract}
Free movement of capital and free movement of broadly understood goods and services has been exercised by nation states through several legal instruments which both determine and reflect a level of a given state's openness to involvement of foreign business entities therein. Specifically, such instruments regulate an extent to which foreign firms may undertake and carry on business activities, employ people, make investments, trade in real estates, trade in foreign currencies, etc. The body of legal regulations making regulatory framework for business activity of foreign entities within a given country has been an element which defines the level of access to that specific market, the level of its internationalization and liberalization. The aim of this article is to analyze regulations of Polish law in the area of legal conditions of undertaking and running business activities on the territory of the Republic of Poland by foreign persons and businesses. The subject is especially topical nowadays, in the context of changes brought in that area by the recent Business Constitution.
\end{abstract}

Keywords: Foreign Person; Foreign Business; Business Activity; Cross-border Provision of Services; Business Constitution.

\section{Introduction}

The phenomenon of free movement of products, technologies, capital as well as of free movement or relocation of institutions, businesses and individuals has been one characteristic element of international integration, closely related with the evolving process of internationalization of socio-economic relations in terms of markets, industries and enterprises. As a consequence of market operation on the global scale, barriers in the global economy are increasingly lifted, in particular in international trade. At the same time, restrictions regarding the movement of capital and financial assets are also gradually abolished. In this context, to eliminate obstacles to foreign direct investments (FDI) so that foreign business entities might compete with domestic ones on equal terms has been one of the key trends evident in the global economy (Nowak, 2017, p. 19-20; Kotyński, 2005, p. 9ff.; Hejduk and Bakalarczyk, 2013, p. 11ff). Thanks to the 
process of globalization and international treaties in the area of free trade, nation states open up to trade exchange and to foreign investments and the principle of free trade makes one of the fundaments upon which the European Community operates (Nowak, 2017a, p. 27). According to the preamble of the Directive of the European Parliament and of the Council on services in the internal market (OJ L 376 of 27.12.2006), the European Community is seeking to forge ever closer links between the States and peoples of Europe and to ensure economic and social progress. In accordance with the provisions of the Treaty establishing the European Community ${ }^{1}$, the internal market comprises an area without internal frontiers in which the free movement of services is ensured as is the freedom of establishment and freedom to provide services within the Community. A competitive market in services is reckoned essential in order to promote economic growth and create jobs in the European Union. The preamble also states that at present numerous barriers within the internal market prevent providers, particularly small and medium-sized enterprises (SMEs), from extending their operations beyond their national borders and from taking full advantage of the internal market. This weakens the worldwide competitiveness of European Union providers. A free market which compels the Member States to eliminate restrictions on cross-border provision of services, while at the same time increasing transparency and information for consumers, would give consumers wider choice and better services at lower prices².

An increased scale of international trade in services results from the processes of deregulation, much intensified in the era of globalization, as well as from technological progress and from quantitative growth of the middle class in emerging economies and developing countries (Budnikowski, 2017, p. 29). The process of globalization heralds an entry into a new qualitative stage of internationalization of business activities, occurring in terms of markets, sectors and businesses (Budnikowski, 2017, p. 599). Then, from the point of view of internationalization of economic relations, the issue of lifting barriers hindering foreign investments in a given country is of crucial importance as they enable the economy to decrease international disproportions in capital endowment. Foreign investments, while not exerting uniform influence across all indexes of general economic condition, still constitute one of driving forces behind the economic growth, certainly contributing to the accrual of any economy's capital resources, which then translates into its increased productivity and higher

At present the Treaty on the Functioning of the European Union (TFEU).

2 Directive 2006/123/EC of the European Parliament and of the Council of 12 December 2006 on services in the internal market (OJ L 276 of 27.12.2006), also referred to as the services directive. 
wages, as well as improved access to modern technologies (Mankiw and Taylor, 2016, p. 80; Burda and Wyplosz, 2013, p. 171; Begg, Vernasca, Fischer and Dornbusch, 2014, p. 480ff). Another aspect that should be emphasized here is the role of increasing foreign investments and foreign capital as an instrument which facilitates overcoming the global financial crisis in the world's economies over a couple of recent years (Nowak, 2015, p. 590).

Free movement of broadly understood services has been exercised by states using a variety of legal instruments which determine an extent to which a given country's economy is open to entry and involvement of foreign entities therein (more about the entities of global economy - see: Orłowska and Żołądkiewicz, 2012, p. 42ff), including, in particular, their right to undertake and run business activities, to employ people, to make investments, to trade in real estates and in currencies, etc. (Budnikowski, 2017, p. 36). Indeed, the body of legal regulations making regulatory framework for business activity of foreign entities within a given country has been an element which defines the level of access to that specific market, the level of its internationalization and liberalization. The regulatory framework defined by the regulator provide the basis for an analysis of an economy in economic terms and define the course for the state's economic policy in this area.

\section{The Business Constitution}

On 30 April 2018 a set of acts entered into force in Poland, defined as the Business Constitution and introducing a profound reform of Polish commercial law. Changes brought by the Business Constitution have been the farthest-reaching, most extensive reconstruction of business environment in which entrepreneurs operate in the Polish market since 1989. The aim of the reform is to improve legal-and institutional conditions of running business activity and to achieve this through proper realization of the constitutional freedom of involvement in commercial activity and through provision of partner relation between business entities and the state (including the rule according to which "everything that is not forbidden by law is allowed", the clause of legal certainty, the rule of presumption of a business entity's fairness, the rule of resolving factual doubts in its favor, friendly interpretation of provisions of law, the rule of resolving legal doubts in favor of an entrepreneur, rules of trust consolidation, of proportionality, impartiality and equal treatment, and, last but not least, the principle of responsibility of officers of public administration 
for the infringements of law, the rule of certainty of law and predictability of solutions made by the state administration bodies, their collaboration in order to achieve complete clarification of a business entity situation, and rendering the communication between an office and a business entity less formal). Another aim of the Business Constitution is to support business, including the provision of friendly legal conditions for starting business activity, reduction of grey economy, provision of institutional support for entrepreneurs through the appointment of the Spokesperson for Small and Medium-sized Entrepreneurs. At the core of the reform there is a new act - The Business Law ${ }^{3}$, replacing a previous act hitherto in force, on the freedom of commercial activity ${ }^{4}$. The new act systematically defines the fundaments of Poland's economic system, providing a set of basic rules regarding business activity. It specifies legal condition of business and the state's obligations towards it. Detailed reforms brought by the Business Law were extensively reported; most noteworthy among them being simplifications for small business and for persons only initiating their business activities. Small commercial activity may be run freely, without the obligation of having it inscribed into the Central Records and Information on the Commercial Activity; persons running such activity are no longer attributed Regon (national business register) number. Individuals only initiating their business activity are released for the period of six months from the duty to pay social insurance contributions. The Act introduces simplified solutions in the area of rationing of business activity. Any previously released approvals or licenses as separate forms of rationing are waived, with only three forms of restrictions remaining: the activities which require business license, activities which require permission and regulated business activities. Also important are changes limiting the control over business activity.

Apart from the new Business Law, the Business Constitution also includes the Act on the Spokesperson for Small and Medium-sized Entrepreneurs 5 , the Act on the Central Records and Information on the Commercial Activity and Information Point for Entrepreneurs ${ }^{6}$, the Act on provisions implementing the

3 The Act of 6 March 2018 - Business Law (Polish Journal of Law 2018, item 646).

4 The Act of 2 July 2004 on the freedom of commercial activity (Polish Journal of Law 2017, item 2168 with later amendments), overruled by the Act of 6 March 2018 - Provisions implementing the Act - Business Law and other acts regarding commercial activities (uniform text: Polish Journal of Law 2018, item 650).

5 The Act of 6 March 2018 on the Spokesperson for Small and Medium-sized Entrepreneurs (Polish Journal of Law 2018, item 648).

6 The Act of 6 March 2018 on the Central Records and Information on the Commercial Activity and Information Point for Entrepreneurs (Polish Journal of Law 2018, item 647 with later amendments). 
Business Law as well as other acts regarding the commercial activity ${ }^{7}$. Moreover, which is of particular importance from the point of view of the present analysis - it also contains the Act on the principles of foreign entrepreneurs' and other foreign persons' participation in trade on the territory of the Republic of Poland 8 .

The former principles concerning business activity run by foreign persons on the territory of Poland were dispersed across several legal acts. As a consequence, the legislative technique used resulted in poor transparency as regards the key conditions for foreign businesses' operation in domestic trade in Poland. Such conditions had been set forth by the Act on the freedom of business activity, the act on the provision of services on the territory of the Republic of Poland ${ }^{9}$, the act setting the rules of running, on the territory of the People's Republic of Poland, commercial activity in the area of small manufacturing by foreign legal persons and individuals ${ }^{10}$. The new Act on the principles of foreign entrepreneurs' and other foreign persons' participation in trade on the territory of the Republic of Poland (further on referred to as the Act) integrates within a single legal act all legal regulations hitherto in force, doing it in a comprehensive and consistent manner, specifying the conditions of foreign entrepreneurs' participation in trade in Poland. In effect of the integrating reform, all these rules have become clearer, more accessible and comprehensible to foreign persons interested in making investments on the territory of Poland. With its scope of regulation, the Act in question implements the Directive 2006/123/EC of the European Parliament and of the Council of 12 December 2006 on services in the internal market.

7 The Act of 6 March 2018 - Provisions implementing the act - Business Law and other acts regarding commercial activity (Polish Journal of Law 2018, item 650).

8 The Act of 6 March 2018 on the principles of foreign entrepreneurs' and other foreign persons' participation in trade on the territory of the Republic of Poland (Polish Journal of Law 2018, item 649 with later amendments).

9 The Act of 4 March 2010 on the provision of services on the territory of the Republic of Poland (Polish Journal of Law 2016, item 893 with later amendments), overruled by the Act of 6 March 2018 - Provisions implementing the act - Business Law and other acts regarding the commercial activity (uniform text: Polish Journal of Law 2018, item 650).

10 The Act of 6 July 1982 setting the rules of running, on the territory of the People's Republic of Poland, commercial activity in the area of small manufacturing by foreign legal persons and individuals (Polish Journal of Law 1989, item 27 with later amendments), overruled by the Act of 6 March 2018 - Provisions implementing the act - Business Law and other acts regarding the commercial activity (uniform text: Polish Journal of Law 2018, item 650). 


\section{The Principles of Running Commercial Activity in Poland by Foreign Persons and Business Entities}

\subsection{Legal and Organizational Forms and Conditions for Running Commercial Activity}

Foreign persons from member states of the European Union or of the European Free Trade Association (EFTA) - parties of the European Economic Area agreement (EEA member states) may undertake and run commercial activity on the territory of the RP on the same rules as citizens of Poland. Foreign person is understood as an individual not having Polish citizenship, a legal person having its domicile abroad or an organized entity which is not a legal person possessing legal capacity, having its domicile abroad. This rule concerns legal entities irrespective of their legal and economic status in their member state of origin.

A similar rule concerns the citizens of third (non-member) states if they meet the conditions defined in Article 4(2) of the Act (especially where they possess permission for permanent stay on the territory of the RP, long-term EU-resident permit, temporary stay permit given on specified terms, a refugee status, subsidiary protection, if they benefit from temporary protection in the RP, possess valid Polish Charter, etc.).

Other foreign persons may undertake and run commercial activity on the territory of the RP only in the form of a limited partnership, limited joint-stock partnership, limited liability company or a joint-stock company. They may also join such entities and take up or acquire their shares or stock, unless relevant international agreements provide otherwise. It should be emphasized in this context that the types of business entities listed above are persons under Polish law, operating pursuant to Polish legislation. The Act excludes the possibility of undertaking or running, by that category of foreign persons, commercial activity on the territory of the RP in any other organizational and legal form than specified, e.g. in the form of general partnership or professional partnership. Joining such business entities is forbidden as well.

It should also be remembered that either taking up or acquiring shares or stock by a foreign person in a commercial company having its domicile on the territory of the RP, as well as any other legal act concerning shares or stock, requires a permit to be given by a minister competent for home affairs, where such act results in the company being an owner or perpetual user of a real estate situated on the territory of the RP becoming a controlled company. Where a commercial company having its domicile on the territory of the RP, 
being an owner or perpetual user of a real estate situated on the territory of the RP, is a controlled company in the first place and its shares or stock are acquired by a foreign person not being its shareholder already, such an act also requires a permit given by a minister competent for home affairs. The above rule results from the principle, adopted in the Polish law, requiring a permit from a minister competent for home affairs, for an acquisition by a foreign person of the right of ownership of a real estate or the right of its permanent use, on the basis of any legal occurrence ${ }^{11}$. As understood by the provisions of the Act on the acquisition of real estates by foreign persons, a foreign person is an individual not possessing Polish citizenship, a legal person having its domicile abroad, a partnership of such persons not having legal personality, having its domicile abroad, established pursuant to foreign states' legislation, as well as a legal person or a commercial company having its domicile on the territory of the RP, either directly or indirectly controlled by the above-mentioned persons or companies. The Act on the acquisition of real estates by foreign persons provides for a number of exemptions from the obligation of obtaining a permit, the most important of which is the exemption from the duty to obtain such permit by foreigners who are citizens or entrepreneurs of the states-parties to the European Economic Area agreement (EEA) or of the Swiss Confederation.

Foreign entrepreneurs from member states (i.e. foreign persons involved in commercial activity in a member state) may set up branches on the territory of the RP. A branch is established exclusively to run business activity on the territory of the RP in the area in which such foreign entrepreneur runs that business activity abroad. Foreign entrepreneurs from countries other than member states may set up branches on the principle of reciprocity, unless relevant ratified international agreements prevent so. A branch set up by a foreign entrepreneur is subject to registration in the Business Register at the National Court Register.

The hitherto-existing principle of no separate legal personality of a foreign entrepreneur's branch in the light of provisions of Polish law has been retained. Hence, a branch constitutes a separated and organizationally autonomous part of the business activity run by a foreign entrepreneur and it operates under the legal personality of that foreign person. Accordingly, the provisions of law require that a foreign entrepreneur who sets up a branch on the territory of the RP also appoint a person authorized in that branch to represent him.

11 The Act of 24 March 1920 on the acquisition of real estates by foreign persons (uniform text: Polish Journal of Law 2017, item 2278). 
According to Article 39(4) of the Act on the National Court Register ${ }^{12}$, such person authorized by a foreign entrepreneur to represent him in the branch has to be explicitly named in the business register.

The new regulation limited the obligation to perform liquidation proceedings, under a procedure and pursuant to rules defined in the provisions of the code of commercial companies concerning a limited liability company liquidation, only to one situation in which a foreign entrepreneur's branch is liquidated in effect of a decision, issued by a minister competent in a given field, on the prohibition of carrying on of a business activity, through a branch, by a foreign entrepreneur. The procedure, defined under the Act, under which a competent minister issues such decision prohibiting business activity being run by a foreign entrepreneur via a branch, does not relate to foreign entrepreneurs from the Community members states. Where a foreign entrepreneur decides on his own to liquidate his branch, then - unlike in previous regulations in this respect - he is no longer obliged to carry on the liquidation proceedings under a procedure and pursuant to rules defined in the provisions of the Code of Commercial Companies concerning a limited liability company liquidation.

A foreign entrepreneur may establish, on the territory of the RP, his representations, whose scope of operation is strictly limited to activities in the field of advertising and promotion of the foreign entrepreneur concerned. Such representation may not be exploited by that foreign entrepreneur to run any commercial activity on the territory of Poland. The establishment and running a business representation requires an entry to be made to the register of foreign enterprises' representations. Quite importantly, such an entry to the register is made for a period of validity of two years since the entry date. Then, upon the foreign entrepreneur's motion the relevant entry may be extended to another period of two years.

In that context it should be added that although the Act on the principles of foreign entrepreneurs' and other foreign persons' participation in trade on the territory of the Republic of Poland has comprehensive character and manages to integrate various provisions of law previously dispersed across many legal acts, still isn't the only source of law specifying the organizational and legal conditions for foreign entities' activity in trade in Poland. What remains beyond its scope is, among other things, the provisions defining the procedures of cross-border mergers of shareholding companies and limited

12 The Act of 20 August 1997 on the National Court Register (uniform text: Polish Journal of Law 2018, item 986 with later amendments). 
joint-stock partnerships (these being regulated under the provisions of the Code of Commercial Companies $\left.{ }^{13}\right)$.

\subsection{Cross-border Provision of Services}

The Act on the principles of foreign entrepreneurs' and other foreign persons' participation in trade on the territory of the RP incorporates the provisions defining the conditions of running cross-border services provision. The pivotal issue from the point of view of that regulation is the notion of "service". This is defined in Article 3(8) of the Act as service performed by a service provider from a member state on its own account, usually against remuneration, including, in particular, construction services, trade services and services provided within the scope of the profession performed. Leaving out the fact that this definition is obviously flawed as it commits the logical idem per idem error ("services are (...) services"), its wording calls for a couple of remarks. Primarily, the scope of its object demands closer specification. It has to be clarified to which type of commercial activity the provisions in question really relate. The definition of service, as included in the Act, relates with its wording to the notion of "service" specified in Article 57 of the Treaty on the Functioning of the European Union, according to which services are benefits, usually delivered against compensation, in the scope in which they are not covered by the provisions on the free movement of goods, capital and persons. Pursuant to Article 57 TFEU, services include, in particular: industrial activity, commercial activity as well as performance of freelance professions. However, according to Article 4(1) of the services directive, a service means any commercial activity run on one's own account, usually delivered against compensation, in line with Article 50 of the Treaty. Therefore, the Community regulations give a basis for rather broad understanding of the notion of service as commercial activity, in particular having industrial or trade nature, or related with performance of freelance professions. While formulating the definition of service, Polish legislator also provides only exemplary listing of types of commercial activities classified under that specific conceptual category. In effect, the catalogue in question is not closed, and its decoding in normative terms has to take into account numerous exemptions defined in Article 12 of the Act (relating to particular categories of commercial activities to which specific provisions of the Act do not apply).

13 The Act of 15 September 2000 - The Code of Commercial Companies (uniform text: Polish Journal of Law 2017, item 1577 with later amendments). 
A service provider from a member state may temporarily render services on the territory of the RP under the principles defined in the provisions of TFEU or in provisions of agreements regulating the freedom of services provision, without being obliged to obtain the entry into the business register in the National Court Register or in the Central Records and Information on the Commercial Activity. A service provider is understood as a foreign entrepreneur from a member state who involves in commercial activity according to legal provisions in force in his country of domicile, while temporarily offering or providing a service on the territory of the RP. Such temporary provision of a service may entail an obligation to obtain a license, a permit, an entry to the regulated activities register, a certificate or another form of rationing, unless provisions of separate acts impose such a duty with regard to public order, public security, security of state, public health or the environment protection. A service provider from a member state may render services on its own or jointly with other service providers from a member state and an exemption from that principle may be awarded if provided for under separate acts and is only admissible for the purpose defined under the act. A service provider is obliged to perform any reporting duties stipulated in the act.

Foreign persons other than an entrepreneur from a member state may render services on the territory of the RP in line with provisions specified in international agreements to which the Republic of Poland is a party or - where no such agreements exist - on the principle of reciprocity.

\section{Conclusion}

Normative reforms in the national legal order introduced in Poland by the Business Constitution in the area defining organizational and legal conditions for foreign investments on the territory of the RP should contribute, through their improved transparency and regulatory consistence, to alleviation of barriers hindering foreign capital's access to the Polish market. In this respect Polish legislator actually implements the Community directive on services and legal conditions provided thereby are intended to foster capital mobility and intensified economic cooperation with foreign business. The profound reform of Polish commercial law, carried out recently in order to improve legal and economic conditions for business and to facilitate relations between the business and the state, should also increase the attractiveness of Polish market for foreign investors. 


\section{References}

Begg, D., Vernasca, G., Fischer, S., Dornbusch, R. (2014). Makroekonomia. Warsaw: PWE. Budnikowski, A. (2017). Ekonomia międzynarodowa. Warsaw: PWE.

Burda, M. and Wyplosz, Ch. (2013). Makroekonomia. Podręcznik europejski. Warsaw: PWE. Directive 2006/123/EC of the European Parliament and of the Council of 12 December 2006 on services in the internal market (OJ L 376 of 27.12.2006).

Hejduk, I.K. and Bakalarczyk, S. (eds). (2013). Global Economics: Past, Present \& Future. Warsaw: Difin.

Kotyński, J. (ed.). (2005). Globalizacja and integracja europejska: szanse and zagrożenia dla polskiej gospodarki. Warsaw: PWE.

Mankiw, N.G. and Taylor, M. (2016). Makroekonomia. Warsaw: PWE.

Nowak, A.Z. (2015). in: A.Z. Nowak, T. Zalega (eds), Makroekonomia. Warsaw: PWE.

Nowak, A.Z. (2017). Globalizacja jako makroekonomiczny megatrend. in: A.Z. Nowak, K. Ryć (eds), Polityka $w$ regionach $w$ warunkach globalizacji. Warsaw: Wydawnictwo Naukowe Wydziału Zarządzania UW.

Nowak, A.Z. (2017). Kryzysy a finansyzacja gospodarki światowej. in: A.Z. Nowak, K. Ryć (eds), Polityka $w$ regionach $w$ warunkach globalizacji. Warsaw: Wydawnictwo Naukowe Wydziału Zarządzania UW.

Orłowska, R. and Żołądkiewicz, K. (2012). Globalizacja and regionalizacja w gospodarce światowej. Warsaw: PWE.

The Act of 15 September 2000 - The Code of Commercial Companies (uniform text: Polish Journal of Law 2017, item 1577 with later amendments).

The Act of 2 July 2004 on the Freedom of Commercial Activity (uniform text: Polish Journal of Law 2017, item 2168 with later amendments).

The Act of 20 August 1997 on the National Court Register (uniform text: Polish Journal of Law 2018, item 986 with later amendments).

The Act of 24 March 1920 on Acquisition of Real Estates by Foreign Persons (uniform text: Polish Journal of Law 2017, item 2278).

The Act of 4 March 2010 on Provision of Services on the territory of the Republic of Poland (uniform text: Polish Journal of Law 2016, item 893 with later amendments).

The Act of 6 July 1982 setting the rules of running, on the territory of the People's Republic of Poland, commercial activity in the area of small manufacturing by foreign legal persons and individuals (uniform text: Polish Journal of Law z 1989 r., item 27 with later amendments)

The Act of 6 March 2018 - The Business Law (Polish Journal of Law 2018, item 646).

The Act of 6 March 2018 - Provisions implementing the Business Law as well as other acts regarding the commercial activity (Polish Journal of Law 2018, item 650).

The Act of 6 March 2018 on the Central Records and Information on the Commercial Activity and Information Point for Entrepreneurs (Polish Journal of Law 2018, item 647 with later amendments).

The Act of 6 March 2018 on the Spokesperson for Small and Medium-sized Entrepreneurs (Polish Journal of Law 2018, item 648).

The Act of 6 March 2018 on the principles of foreign entrepreneurs' and other foreign persons' participation in trade on the territory of the Republic of Poland (Polish Journal of Law 2018, item 649 with later amendments). 